\title{
Yield and morphophysiological indices of irrigated rice genotypes in contrasting ecosystems ${ }^{1}$
}

\author{
Marcos Paulo dos Santos 2 , Alencar Junior Zanon ${ }^{3}$, \\ Santiago Vianna Cuadra ${ }^{4}$, Silvio Steinmetz ${ }^{4}$, João Rodrigo de Castro ${ }^{2}$, Alexandre Bryan Heinemann ${ }^{5}$
}

\begin{abstract}
Rice phenology and development are events controlled by environmental and genetic factors, and the yield potential of the crop is defined by their interaction. This study aimed at analyzing the performance of irrigated rice genotypes in contrasting ecosystems and their effects on morphophysiological characteristics. Two ecosystems (tropical and subtropical) were analyzed, as well as cultivars recommended for tropical (BRS Catiana and BRS Jaçanã) and subtropical (BRS Pampa, BRS 7 Taim and IRGA 424) regions. The experiments were arranged in a complete randomized block design, with four replicates, being the factors the genotypes, sowing times and sites. The phenological development, biomass dynamics, radiation use efficiency and grain yield were evaluated. The accumulated degree-days demand for flowering decreased faster in the tropical ecosystem than in the subtropical ecosystem for late sowing. The radiation use efficiency values were similar in the subtropical ecosystem and yield was high for all sowing dates. On the other hand, the tropical ecosystem showed a high variation for radiation use efficiency values and yield. The higher accumulation of degree-days and solar radiation during the reproductive and grain-filling phases contributed to increase yield in both ecosystems.
\end{abstract}

KEYWORDS: Oryza sativa L.; ecophysiology; sowing date; solar radiation.

\section{INTRODUCTION}

Rice (Oryza sativa) is the second most cultivated cereal crop in the world and it provides $21 \%$ of the energy and $15 \%$ of the protein consumed by humans (Zibaee 2013). It is cultivated in different ecosystems, from the humid tropics to the temperate

\section{RESUMO}

Produtividade e índices morfofisiológicos de genótipos de arroz irrigado em ecossistemas contrastantes

A fenologia e o desenvolvimento da planta de arroz são eventos controlados por condições ambientais e fatores genéticos, sendo o potencial produtivo da cultura definido pela sua interação. Objetivou-se analisar o desempenho de genótipos de arroz irrigado em ecossistemas contrastantes e seus efeitos nas características morfofisiológicas. Dois ecossistemas foram analisados (tropical e subtropical), bem como cultivares recomendadas para regiões tropicais (BRS Catiana e BRS Jaçanã) e subtropicais (BRS Pampa, BRS 7 Taim e IRGA 424). O delineamento foi o de blocos casualizados, com quatros repetições, sendo fatores os genótipos, épocas de semeadura e sítios. Avaliou-se o desenvolvimento fenológico, dinâmica da biomassa, eficiência no uso da radiação e a produtividade de grãos. No ecossistema tropical, a demanda de grausdia acumulados para o florescimento decresceu com maior magnitude que no subtropical, para as semeaduras tardias. No ecossistema subtropical, os valores de eficiência no uso da radiação foram similares e a produtividade elevada para todas as épocas de semeadura. Já no tropical, verificou-se variação nos valores de eficiência no uso da radiação e produtividade. Maiores acúmulos de graus-dia e de radiação solar na fase reprodutiva e de enchimento de grãos contribuíram para o aumento da produtividade em ambos os ecossistemas.

PALAVRAS-CHAVE: Oryza sativa L.; ecofisiologia; época de semeadura; radiação solar.

zone, and the impact of this climatic variability differs regionally (Wassmann et al. 2009).

Brazil produces irrigated rice in two ecosystems: subtropical and tropical. In the subtropical ecosystem, rice is cultivated in southern Brazil, accounting for $70 \%$ of the domestic production, with an average yield of $7 \mathrm{Mg} \mathrm{ha}^{-1}$

1. Manuscript received in Mar./2017 and accepted for publication in Aug./2017 (http://dx.doi.org/10.1590/1983-40632016v4745955).

2. Universidade Federal de Goiás, Escola de Agronomia, Goiânia, GO, Brasil. E-mails: marcospaulo_agronomo@hotmail.com, joaorodrigo2005@gmail.com.

3. Instituto Rio Grandense do Arroz, Cachoeirinha, RS, Brasil.E-mail: alencarzanon@hotmail.com.

4. Empresa Brasileira de Pesquisa Agropecuária (Embrapa Clima Temperado), Pelotas, RS, Brasil. E-mails: santiago.cuadra@embrapa.br, silvio.steinmetz@embrapa.br.

5. Empresa Brasileira de Pesquisa Agropecuária(Embrapa Arroz e Feijão), Santo Antônio de Goiás, GO, Brasil.

E-mail: alexandre.heinemann@embrapa.br. 
(Breseghello \& Neves 2016). In the tropical region, irrigated rice is produced mainly in the states of Goiás, Tocantins, Mato Grosso do Sul, Maranhão, Ceará, Pernambuco, Sergipe and Alagoas, and accounts for only $10 \%$ of the domestic production, with an average yield of $5 \mathrm{Mg} \mathrm{ha}^{-1}$ (Nascente \& Santos 2016). Upland rice accounts for the remaining $20 \%$. For reasons related to food safety and logistics, those states cannot depend on rice from southern Brazil. Concentrating the production into a single region puts a risk to the national food security, mainly due to the intensity of climatic events such as "El Ninõ" and "La Ninã". In addition, the diversification of the agricultural matrix of the aforementioned states is important.

A total of $25-38 \%$ of the variation in rice yield in Brazil is explained by intra- and inter-region climatic variability (Ray et al. 2015). Climatic factors such as photoperiod, solar radiation and air temperature directly affect rice yield (Acreche et al. 2009, Van Oort et al. 2011). The main problems caused by climatic factors are cycle changes in photoperiod-sensitive cultivars, increased spikelet sterility due to extreme temperatures at the time of microsporogenesis and flowering, and decreased yield due to low accumulation of solar radiation at the grain-filling phase (Dingkuhn et al. 2015, Sosbai 2016). Interactions of climatic factors affecting morphophysiological characteristics of plants impact the yield of irrigated rice and vary with growing seasons. Management strategies such as widening the current sowing window and defining specific sowing times for microregions are potential tools to reduce the yield gap in environments of irrigated rice in Brazil.

Therefore, this study aimed at determining the impacts of crop ecosystems and sowing time on the morphophysiological characteristics and grain yield of irrigated rice cultivars.

\section{MATERIAL AND METHODS}

The experiments were carried out in the Brazilian cities of Goianira (lat $=-16.41$, long $=$ -49.38), Goiás (GO) state, Pelotas (lat $=-32.08$, long $=-52.88)$ and Cachoerinha (lat $=-29.95$, long $=$ -51.08), Rio Grande do Sul (RS) state. These trials were designated as $\mathrm{GO}_{1}$ 14/15(1), GO_15/16(2), GO_15/16(3) (Goianira, 2014/2015 and 2015/2016 harvest years), PE_14/15 (Pelotas, 2014/2015 harvest year) and CA_15/16 (Cachoerinha, 2015/2016 harvest year).

According to the Köppen classification, the climate of Goianira is tropical Savannah (Aw), with seasonal rainfall. Pelotas and Cachoeirinha are classified as subtropical humid or temperate (Cfa), with warm summers and regular rainfall (Alvares et al. 2014). Soils at the experimental sites are classified as dystrophic Haplic Gleysol in floodplain (Santos et al. 2013), Eutrophic Haplic Planosol and dystrophic Haplic Gleysol (Streck et al. 2008), respectively for Goianira, Pelotas and Cachoeirinha.

All the trials were established by direct seeding, except for GO_14/15(1), which was transplanted. The experiments were arranged in a randomized complete block design, with the factors being genotypes, sowing times and sites, with four replicates. The experimental plots consisted of six $15-\mathrm{m}$ rows, spaced $0.17 \mathrm{~m}$ apart. The subtropical cultivars BRS Pampa, BRS 7 Taim and IRGA 424 and the tropical cultivars BRS Jaçanã and BRS Catiana were evaluated. In the GO 14/15(1) trial, $10 \mathrm{~kg} \mathrm{ha}^{-1}$ of nitrogen $(\mathrm{N})$ were applied at transplanting and $120 \mathrm{~kg} \mathrm{ha}^{-1}$ as topdressing. In the GO_15/16(2) and GO_15/16(3) trials, $12 \mathrm{~kg} \mathrm{ha}^{-1}$ of $\mathrm{N}$ were applied as basal and $100 \mathrm{~kg} \mathrm{ha}^{-1}$ as topdressing. In the PE_14/15 and CA $15 / 16$ trials, $16 \mathrm{~kg} \mathrm{ha}^{-1}$ of $\mathrm{N}$ were applied as basal and $150 \mathrm{~kg} \mathrm{ha}^{-1}$ as topdressing. The control of insect pests, diseases and weeds was carried out according to the needs of the crop in the respective sites.

For the phenological analysis of the cultivars, data on emergence dates and phenological stages were collected: V6 (6th leaf emerges on the main stem), R1 (panicle initiation), R4 (flowering) and R9 (complete panicle maturity), according to the scale proposed by Counce et al. (2000). R1 was determined using the methodology by Steinmetz et al. (2009). These data were collected only in the trials GO_15/16(3) and CA_15/16. The GO_15/16(3) trail consisted of five sowing times $(20 / 10 / 2015,05 / 11 / 2015,17 / 11 / 2015$, $4 / 12 / 2015$ and $12 / 17 / 2015)$ and the CA_15/16 trial of three sowing times $(10 / 10 / 2015,9 / 11 / 2015$ and 12/3/2015).

For determination of the biomass dynamics of total above dry matter, plant samples separated into stems, leaves and panicles were weekly collected and oven dried at $75^{\circ} \mathrm{C}$, for $48 \mathrm{~h}$ (Teixeira et al. 2015). Collections were performed in the trials GO_14/15(1), GO_15/16 (2), PE_14/15 
and CA_15/16. GO_14/15 had two sowing dates [10/11/2014 (SD2) and 12/18/2014 (SD3)] for the cultivars BRS Catiana, BRS Jaçanã, BRS Pampa and BRS 7 Taim. GO_15/16(2) and PE_14/15 had one sowing date each [09/28/2015 (SD1) and 03/11/2014 (SD2), respectively]. All cultivars were evaluated in GO_15/16(2), while in PE_14/15 only the cultivars BRS Jaçanã, BRS Pampa and BRS 7 Taim were evaluated. CA_15/16 had three sowing dates [01/10/2015 (SD1), 09/11/2015 (SD2) and 03/12/2015 (SD3)] and all cultivars were evaluated, except for BRS Jaçanã, which was planted only in the first sowing season (SD1).

The total above dry matter dynamics was estimated using the logistic model, as described by Teixeira et al. (2015):

$$
\mathrm{TDM}=\mathrm{a} /\left\{1+\left[\mathrm{b}^{*} \exp ^{(\mathrm{c} * \mathrm{ADD})}\right]\right\}
$$

where: $T D M$ is the total above dry matter $\left(\mathrm{kg} \mathrm{ha}^{-1}\right)$; $a, b$ and $c$ the asymptote, inflection and scale parameters, respectively; and $A D D$ the accumulated degree-days after emergence, calculated as described in Bouman et al. (2001) and detailed by Heinemann et al. (2016).

Phenological development was quantified using the phenological development rate $\left({ }^{\circ} \mathrm{C} \mathrm{d}^{-1}\right)$, which was proposed by Bouman et al. (2001) and detailed by Heinemann et al. (2016).

Cardinal temperatures (base, optimum and maximum temperature; ${ }^{\circ} \mathrm{C}$ ) were determined based on the tests performed in Goianira, using a minimum mean squared error function, which considers the number of days observed (obtained in the field trials described above) and number of simulated days for the vegetative, reproductive and grain-filling phases. The phenological development rate for the vegetative, reproductive and grain-filling phases were calculated by the following equations:

$$
\begin{aligned}
& \operatorname{DVR}_{\mathrm{V}}=\frac{(0.65-0)}{\mathrm{ADD}_{\mathrm{v}}} \\
& \mathrm{DVR}_{\mathrm{R}}=\frac{(1-0.65)}{\mathrm{ADD}_{\mathrm{r}}} \\
& \mathrm{DVR}_{\mathrm{E}}=\frac{(2-1)}{\mathrm{ADD}_{\mathrm{g}}}
\end{aligned}
$$

where ${ }_{V}$ stands for vegetative (emergence to panicle initiation), ${ }_{R}$ for reproductive (panicle initiation to flowering), ${ }_{g}$ for grain filling (flowering to complete grain maturity) and $A D D$ for accumulated degreedays $\left({ }^{\circ} \mathrm{C} \mathrm{d}\right)$.

The base, optimum and maximum temperature values with best adjustments for Goianira were $10^{\circ} \mathrm{C}, 29^{\circ} \mathrm{C}$ and $37^{\circ} \mathrm{C}$, respectively. In this study, we assumed that the cultivars have similar base, optimum and maximum temperature for the sites Pelotas and Cachoeirinha. This allowed a comparative analysis for the performance of these cultivars in tropical and subtropical ecosystems.

The radiation use efficiency $\left(\mathrm{g} \mathrm{MJ}^{-1}\right)$ was calculated by the coefficient of linear regression between the biomass dynamics of total dry matter $\left(\mathrm{kg} \mathrm{ha}^{-1}\right)$ and the photosynthetically active accumulated radiation $\left(\mathrm{MJ} \mathrm{m}^{-2}\right)$. Differences in the radiation use efficiency between cultivars and sites were compared using confidence intervals at $5 \%$. The impact of the photosynthetically active radiation (PAR) accumulated from -10 to +25 days after flowering on the cultivars yield in the crop ecosystems was calculated as described by Dingkuhn et al. (2015).

The trends of maximum and minimum temperature accumulation in the reproductive stage (panicle initiation to flowering) for the tropical ecosystem Goianira were obtained using the ORYZA model, which simulates rice growth, development and yield (Bouman et al. 2001). Phenology was calibrated and validated for the cultivars in study by calculating the phenological development rate, as previously described. The model was applied to the potential condition, considering the genotypic characteristics of the cultivars and the climatic variables global solar radiation, maximum and minimum temperature. Sowing was carried out from October to December, every 10 days. A 32-year (1980-2012) climatological series of daily data was obtained from the climatological station located in the experimental area.

Yield was determined in all trials and analyzed by pooled analysis of variance, followed by the comparison with the least significant difference test at $5 \%$ (for cultivars, sites and sowing times). However, the yield components (number of grains per $\mathrm{m}^{2}$, percentage of fertile spikelets and number of panicles per $\mathrm{m}^{2}$ ) were determined only for the experiments performed in Goianira and analyzed by correlation.

To determine the response of rice grain yield to accumulated degree-days and global radiation in the developmental phases, the differences in yields of 
the cultivars were normalized using the standardized average method proposed by Fan \& Liu (2010). The normalized data were referred to as "relative data" and calculated using the equation bellow:

$$
\mathrm{RGY}=\frac{\text { Yield_C X site Y }}{\text { Average Yield_C }}
$$

where: $R G Y$ stands for relative grain yield; Yield_C for yield of a given cultivar $\left(\mathrm{kg} \mathrm{ha}^{-1}\right) ; X$ for SD1, SD2, SD3; $Y$ for Cachoeirinha, Pelotas and Goianira; and Average Yield_C for the average yield of a given cultivar, considering all sites and sowing dates.

\section{RESULTS AND DISCUSSION}

In Goianira (Figure 1a), advancing the sowing time increased the demand for accumulated degreedays (ADD) to reach V6, especially in September, what was not recorded in Cachoeirinha (Figure 1b).

In the tropical ecosystem, the accumulated degree-days demand for flowering decreased more than in the subtropical ecosystem, for late sowing. This is because in the tropical ecosystem there is a higher ADD accumulation in a shorter time, due to the higher thermal amplitude in the summer. In this study, the mean thermal amplitude in the cropping periods was $13.4{ }^{\circ} \mathrm{C}$ and $9.8^{\circ} \mathrm{C}$, respectively for Goianira and Cachoeirinha.
The cultivars used in this study are considered modern and less photoperiod-sensitive, and their development is basically determined by temperature (Santos 2016). The closer to the Equator, the higher the average air temperature, hence there is a change in the crop cycle (Lorençoni et al. 2010). The reduction in the ADD demand for flowering, due to delay in sowing, reflected this trend, because the latitude of Goianira is lower than that for Cachoeirinha. The development rate in the reproductive phase differed between crop sites only for BRS Catiana, and this rate was lower in Goianira. However, the opposite occurred in the grain-filling phase, with a higher rate in Goianira, what explains the equivalence of the cultivar cycle time in both environments, which was 128 days.

In general, the grain-filling phase and the period between flowering and complete maturity of grains are basically constant among the cultivars in both sites, but was longer in Goianira, regardless of the sowing season. In this period, there is a minimum variation in the relative development rate in the reproductive phase, for cultivars with delayed sowing, particularly in Goianira (Table 1). In this period, rice is less temperature-sensitive and the number of days may be considered to estimate the length of this phase. Physiologically, in this period (anthesis to physiological maturity), the plant

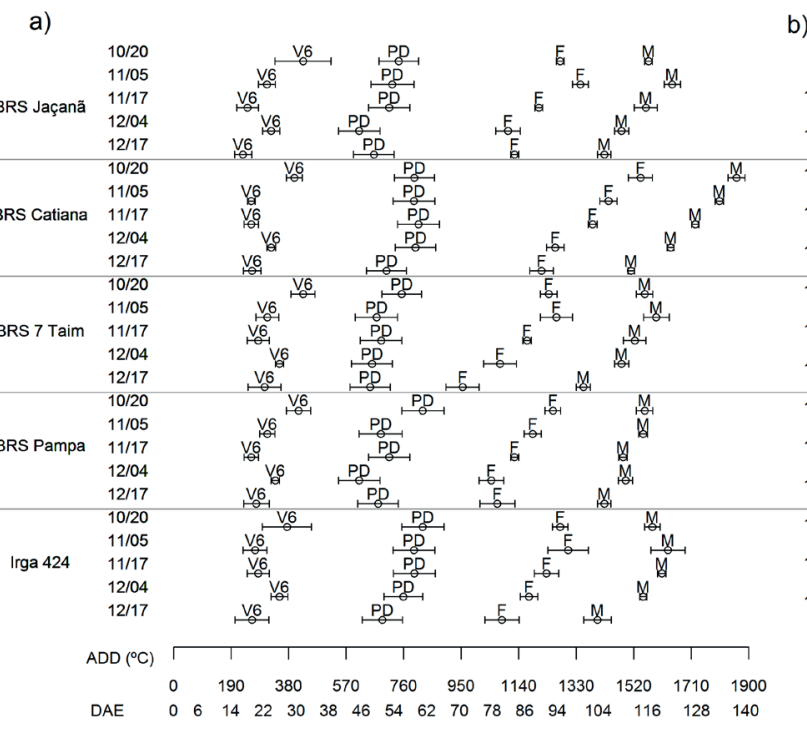

b)

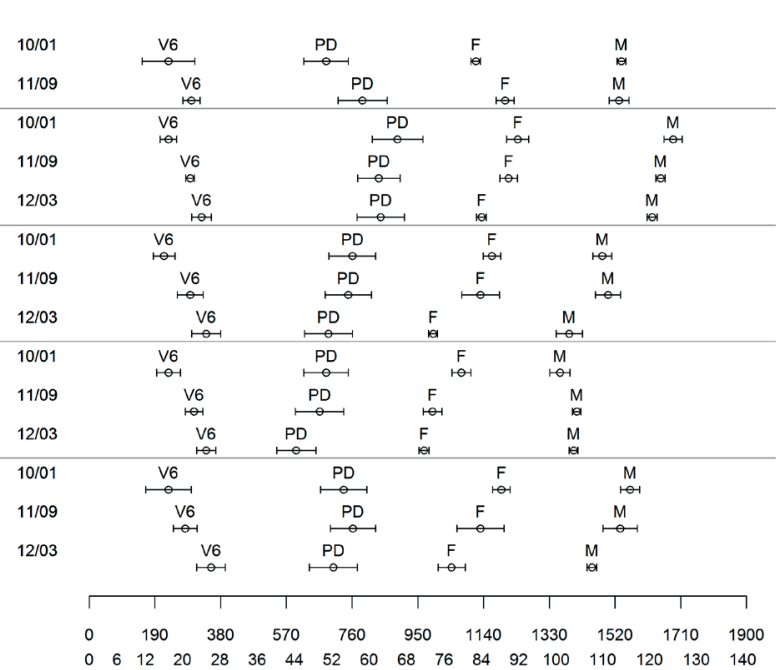

Figure 1. Demand for accumulated degree-days (ADD) and days after emergence (DAE) for irrigated rice cultivars grown in Goianira - GO (a) and Cachoeirinha - RS (b) at the sowing dates. E = emergence; V6 = sixth leaf emitted on the main stem; $\mathrm{PD}=$ panicle differentiation; $\mathrm{F}$ = flowering; $\mathrm{M}=$ complete grain maturation. The horizontal segment represents the standard error and the dates the sowing times. 
begins to senescence, becoming less sensitive to the variation in air temperature (Van Oort et al. 2011).

The sowing time had no significant impact on the radiation use efficiency of cultivars in the subtropical ecosystem (Figures $2 \mathrm{~b}$ and $2 \mathrm{~d}$, red circle). This result shows that the sowing window (OctoberDecember) in the subtropical ecosystem caused no variation in the radiation use efficiency. However, in the tropics, there was a reduction in the radiation use efficiency values at the sowing date SD2, for the BRS Catiana, BRS Jaçanã, BRS Pampa and BRS 7 Taim cultivars. This is explained by the lower accumulation of biomass found for all cultivars at this site and sowing time (Figures $3 \mathrm{a}, 3 \mathrm{c}, 3 \mathrm{~d}$ and $3 \mathrm{e}$ ). In turn, the dynamics of biomass accumulation is also related to the accumulation of minimum temperatures in the reproductive phase, which was lower at SD2 (Figure 4d).

Gunawardena et al. (2003) and Deng et al. (2015) reported that the occurrence of low

Table 1. Length of the phenological phases (days), development rates and mean standard error for the vegetative (DVR $)$, reproductive $\left(\mathrm{DVR}_{\mathrm{R}}\right)$ and grain filling $\left(\mathrm{DVR}_{\mathrm{E}}\right)$ phases, for irrigated rice cultivars in two ecosystems.

\begin{tabular}{|c|c|c|c|c|c|c|c|}
\hline \multirow{2}{*}{ Site } & \multirow{2}{*}{ Phase } & \multicolumn{5}{|c|}{ Cultivar } & \multirow{2}{*}{ Mean } \\
\hline & & BRS Catiana & BRS Jaçanã & BRS Pampa & BRS 7 Taim & IRGA 424 & \\
\hline \multirow{6}{*}{$\begin{array}{l}\text { Tropical } \\
\text { Goianira - GO }\end{array}$} & Days & $59 \pm 2.19$ & $51.8 \pm 2.73$ & $53.2 \pm 2.32$ & $51.8 \pm 1.72$ & $58.2 \pm 1.95$ & - \\
\hline & $\mathrm{DVRv}^{\mathrm{a}}$ & $13.8 \mathrm{aA}$ & $14.1 \mathrm{aA}$ & $12.9 \mathrm{aA}$ & $12.3 \mathrm{aA}$ & $13.3 \mathrm{aA}$ & $13.30 \mathrm{~A}$ \\
\hline & Days & $43.6 \pm 3.69$ & $38.6 \pm 2.01$ & $32.2 \pm 1.35$ & $34 \pm 3.39$ & $33 \pm 1.37$ & - \\
\hline & $\mathrm{DVR}_{\mathrm{R}}{ }^{\mathrm{a}}$ & $6.13 \mathrm{aB}$ & $6.78 \mathrm{aA}$ & $8.09 \mathrm{aA}$ & $8.02 \mathrm{aA}$ & $7.92 \mathrm{aA}$ & $7.38 \mathrm{~B}$ \\
\hline & Days & $26.4 \pm 1.32$ & $24.4 \pm 1.16$ & $27.4 \pm 1.63$ & $27 \pm 1.48$ & $25.8 \pm 1.15$ & - \\
\hline & $\mathrm{DVR}_{\mathrm{E}}^{\mathrm{a}}$ & $29.6 \mathrm{aA}$ & $31.2 \mathrm{aA}$ & $27.8 \mathrm{aA}$ & $27.8 \mathrm{aA}$ & $29.5 \mathrm{aA}$ & $29.20 \mathrm{~A}$ \\
\hline \multirow{6}{*}{$\begin{array}{l}\text { Subtropical } \\
\text { Cachoeirinha - RS }\end{array}$} & Days & $67.6 \pm 2.17$ & $62 \pm 0.5$ & $52.7 \pm 2.53$ & $59 \pm 2.53$ & $58.6 \pm 2.16$ & - \\
\hline & $\mathrm{DVRV}^{\mathrm{a}}$ & $14.4 \mathrm{aA}$ & $15.2 \mathrm{aA}$ & $14.1 \mathrm{aA}$ & $14.5 \mathrm{aA}$ & $14.3 \mathrm{aA}$ & $14.40 \mathrm{~A}$ \\
\hline & Days & $26 \pm 2.08$ & $33 \pm 3$ & $27 \pm 0.57$ & $27 \pm 2.51$ & $29 \pm 2.30$ & - \\
\hline & $\mathrm{DVR}_{\mathrm{R}}^{\mathrm{a}}$ & $10.3 \mathrm{aA}$ & $8.01 \mathrm{aA}$ & $9.62 \mathrm{aA}$ & $9.74 \mathrm{aA}$ & $9.06 \mathrm{aA}$ & $9.44 \mathrm{~A}$ \\
\hline & Days & $35 \pm 1.52$ & $26 \pm 2.0$ & $29.3 \pm 3.28$ & $28 \pm 1.73$ & $30.6 \pm 0.88$ & - \\
\hline & $\mathrm{DVR}_{\mathrm{E}}^{\mathrm{a}}$ & $21.8 \mathrm{aB}$ & $29.31 \mathrm{aA}$ & $27.0 \mathrm{aA}$ & $27.7 \mathrm{aA}$ & $25.2 \mathrm{aA}$ & $25.90 \mathrm{~B}$ \\
\hline
\end{tabular}

${ }^{a}$ Relative development rate (DVR x $10^{-4}$ ). Small letters in the rows compare cultivars within crop sites and capital letters compare crop sites for each cultivar and at each development phase, at $5 \%$.

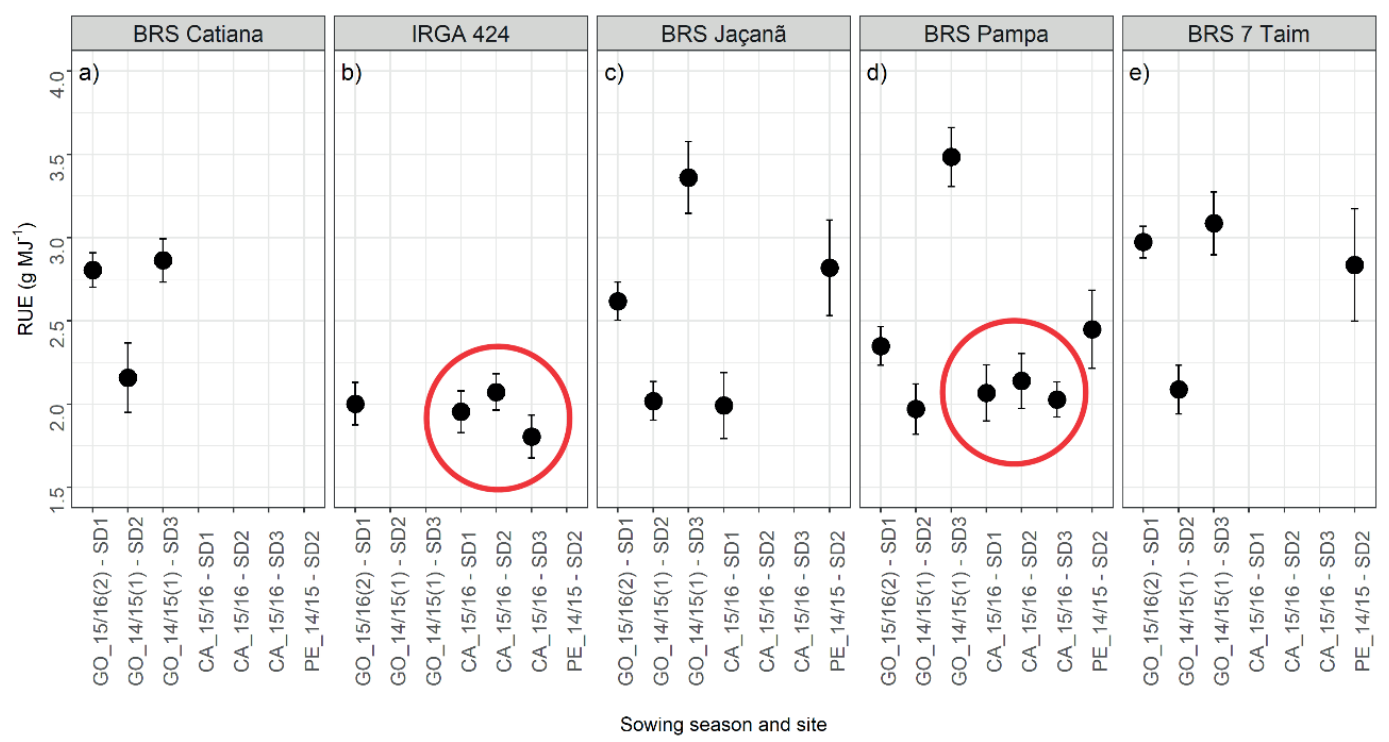

Figure 2. Radiation use efficiency (RUE) and mean error (vertical bar) for the BRS Catiana, IRGA 424, BRS Jaçanã, BRS Pampa and BRS 7 Taim cultivars, in the tropical [Goianira (GO)] and subtropical [Cachoeirinha (CA) and Pelotas (PE)] ecosystems. The red circle in figures $b$ and $d$ show the radiation use efficiency obtained in the subtropical ecosystem for the IRGA 424 and BRS Pampa cultivars. 
temperatures in the reproductive phase reduces photosynthesis and may increase spikelet sterility, compromising the total biomass accumulation. The difference in radiation use efficiency values presented by the cultivars due to sowing times shows the importance of evaluating and determining suitable sowing times for areas of irrigated rice production in Brazil.

Using the ORYZA simulation model, the accumulation of maximum and minimum air temperature were obtained for the reproductive phase (Figures $5 \mathrm{a}$ and $5 \mathrm{~b}$ ). Sowing from November onwards tended to decrease the accumulated minimum temperature and increase the accumulated maximum temperature in Goianira (tropical ecosystem), representing an increase in the thermal amplitude in this site.

This increase in the thermal amplitude, due to the lower accumulation of minimum air temperatures (Figures $4 \mathrm{~d}$ and $5 \mathrm{a}$ ) and higher accumulation of maximum air temperatures (Figure $5 b$ ), in the tropical ecosystem with sowing in November, affected the plant biomass accumulation. Rice has a C3-type photosynthetic metabolism and high temperatures induce a net decrease in photosynthesis and increased photorespiration, resulting in lower

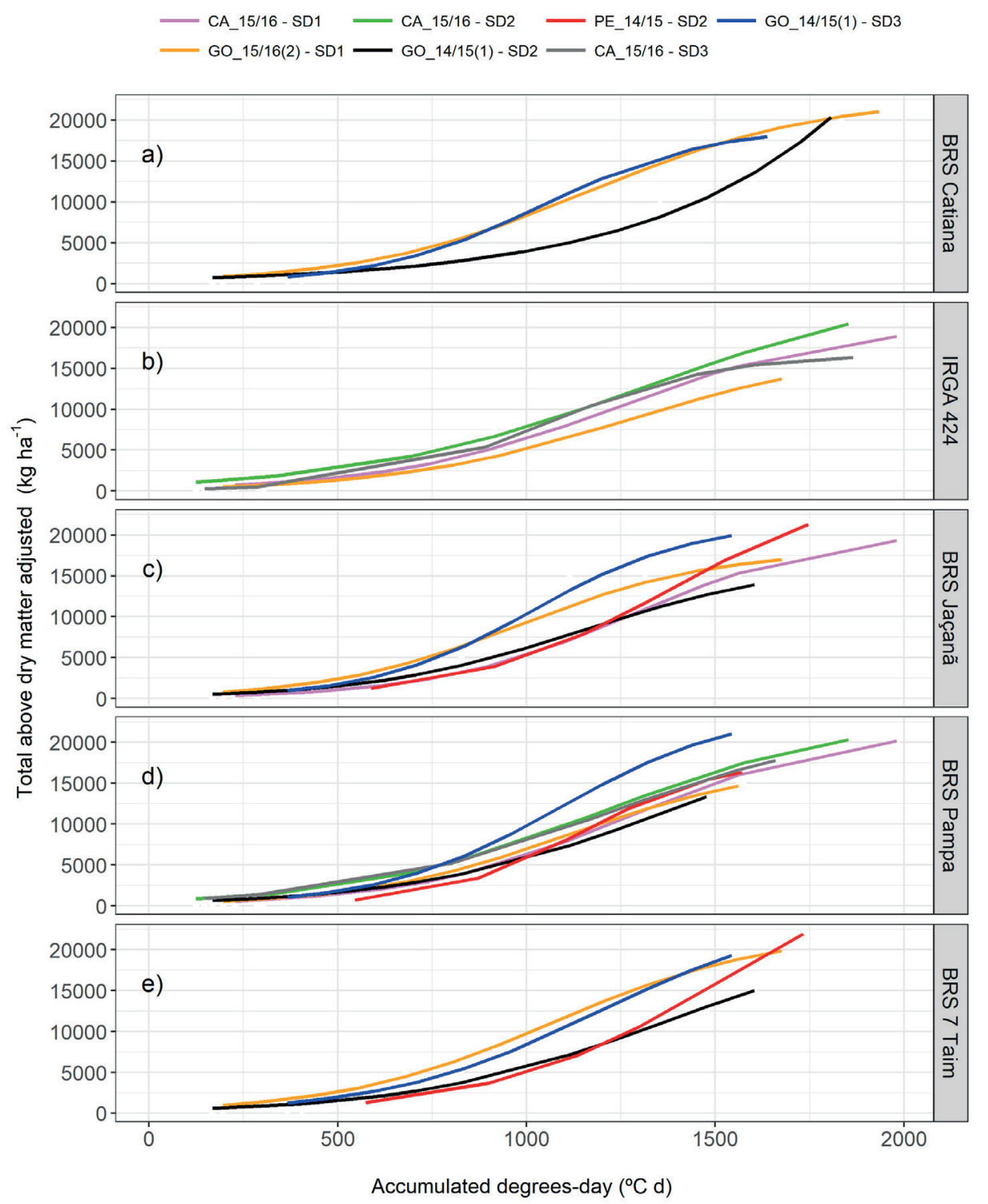

Figure 3. Biomass dynamics of total dry matter adjusted for the BRS Catiana (a), IRGA 424 (b), BRS Jaçanã (c), BRS Pampa (d) and BRS 7 Taim (e) cultivars, as a function of accumulated degree-days for the experimental sites and sowing times. 
biomass accumulation per unit area (Kerbauy 2008). The trend for increasing the thermal amplitude for the sowing in November in the tropical ecosystem is shown in Figures 5a, 5b and 4d (2014/2015 harvest year) and has a consequent impact on the radiation use efficiency (Figure 2).

In this study, yield was correlated with the increase in the number of panicles per $\mathrm{m}^{2}$ only for the BRS Pampa and BRS Taim cultivars, both with positive correlation (Figures $6 \mathrm{~d}$ and $6 \mathrm{e}$ ).

The lack of correlation between yield and number of panicles per $\mathrm{m}^{2}$ for the other cultivars is due to the plasticity that some genotypes show in the tillering phase, which promotes the adjustment of yield components in unfavorable conditions to tillering (Lima et al. 2010).

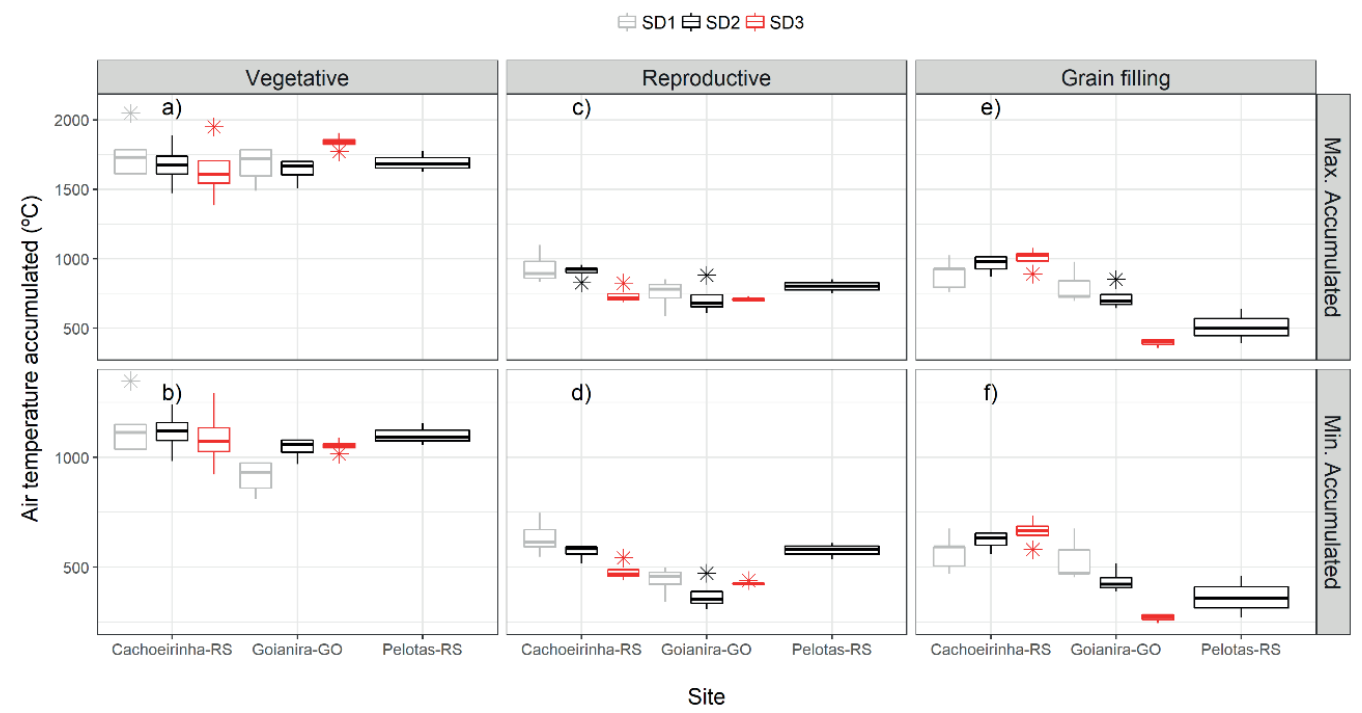

Figure 4. Boxplot of accumulation of maximum (a, c, e) and minimum (b, d, f) temperatures throughout the field trials, in the vegetative, reproductive and grain-filling phases, for the sowing times October (SD1), November (SD2) and December (SD3). Lines extending above and below each box indicate the 75 th and 25 th percentile of the data set. The horizontal line that cuts through the box indicates the median.

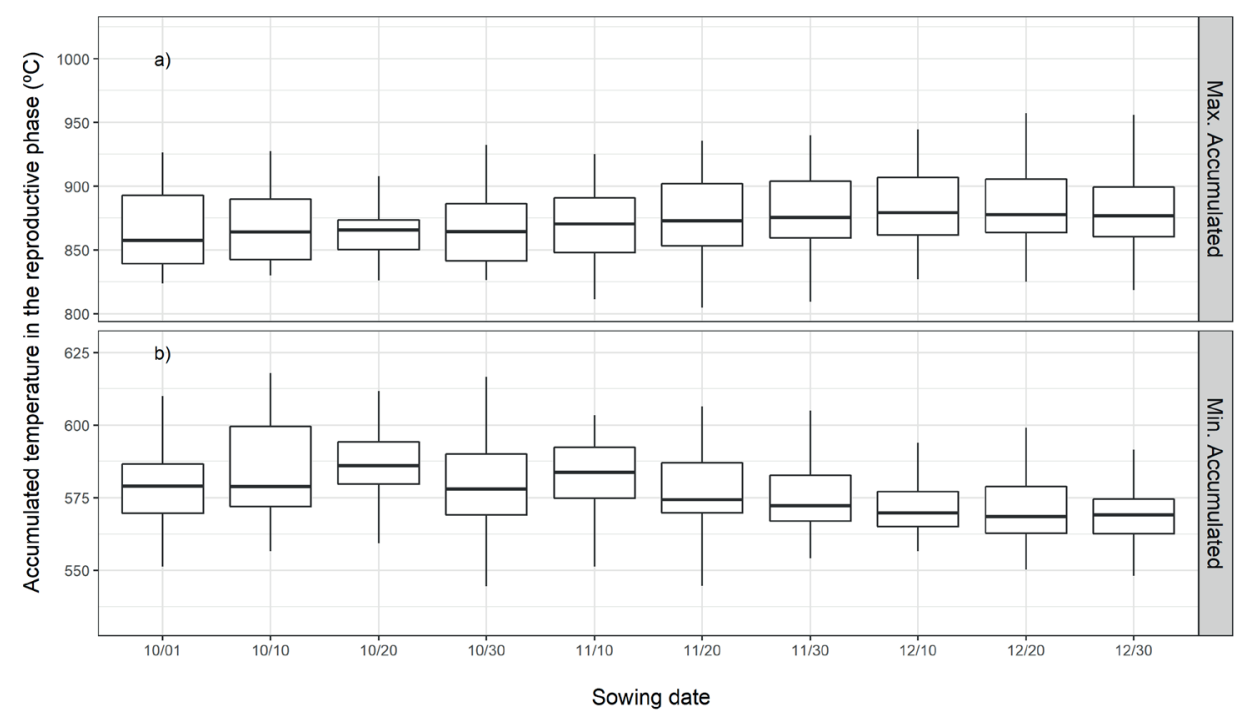

Figure 5. Boxplot of accumulation of maximum (a) and minimum (b) temperatures from 1980 to 2012, in the reproductive phase, for sowing from October to December in Goianira - GO (tropical ecosystem), using the ORYZA rice simulation model. Lines extending above and below each box indicate the 75 th and 25 th percentile of the data set. The horizontal line that cuts through the box indicates the median. 
The potential number of panicles per plant is defined between V3/V4 and R1 (ten days after the panicle primordium becomes visible), and depends mainly on the number of shoots per plant (tillering), which is defined by genetic (cultivar) and environmental factors (Dalchiavon et al. 2012). From the agronomic point of view, it is desired that a linear increase occurs in the number of panicles per $\mathrm{m}^{2}$, which most often results in higher yields, as it was found for BRS Pampa and BRS Taim cultivars (Figure 6). However, this response relies on several factors, including flowering period, pollination and fertilization, and it is still essentially linked to the ability of the genotype to translocate carbohydrates to the panicles (Lima et al. 2010, Dalchiavon et al. 2012).

External factors such as low temperature during microsporogenesis (Martins et al. 2007), as well as excessive doses of nitrogen fertilizers, may also change this yield component. Krishnan et al. (2007) point out that limitations in rice production caused by extreme temperatures can be mitigated, at least in part, by changing the sowing time and selecting genotypes that produce more panicles per $\mathrm{m}^{2}$ and with greater spikelet fertility. Another advantage of using cultivars responsive to the increase in the number of panicle per $\mathrm{m}^{2}$, for instance, BRS Pampa and BRS Taim, is the possibility of reducing the plant stand, as tillering increases with less competition between plants (Fiorezi \& Rodrigues 2014), what allows achieving a seed cost reduction.

There was interaction among cultivars, sowing times and crop sites for grain yield (Table 2). In the tropical ecosystem, lower yields occurred at SD2 for all cultivars, whereas, in the subtropical ecosystem, the highest yields were recorded at this sowing time. IRGA 424 stood out in both ecosystems with the highest yields. In Pelotas, the highest yield was recorded for BRS Taim. All cultivars varied the yield with sowing time. The smallest variations in yield were observed for BRS Pampa and BRS 7 Taim, in Cachoeirinha. This shows that these cultivars are adapted to this site and may be sown in a wider period range (October-December), with lower yield losses, while the other cultivars are more suitable for sowing at specific times to reach a maximum yield.

The yield of all cultivars was higher in the subtropical ecosystem (Table 2). This is related to the greater accumulation of ADD and solar global radiation in this ecosystem during development. For a same site, ADDs were similar between sowing times for most cultivars. The accumulation of global radiation showed a greater variation for sowing times in Cachoeirinha.

Although in Goianira there was a minimal variation in the accumulated global radiation and ADD (Table 2), the lowest rates of yield/ADD and yield/accumulated-PAR were recorded in November (SD2) (Figures 7a and 7b). This is consistent with the low radiation use efficiency values found for all cultivars at that time (Figure 2), as well as the occurrence of lower accumulations of minimum temperatures in the reproductive phase (Figure 4d).

In Cachoeirinha, the highest yield/ADD rate occurred at SD2, being $6.4 \%$ and $15.9 \%$ higher

Site - Season $\square$ GO_15/16(2) - SD1 ○ GO_14/15(1) - SD2 $\triangle$ GO_14/15(1) - SD3

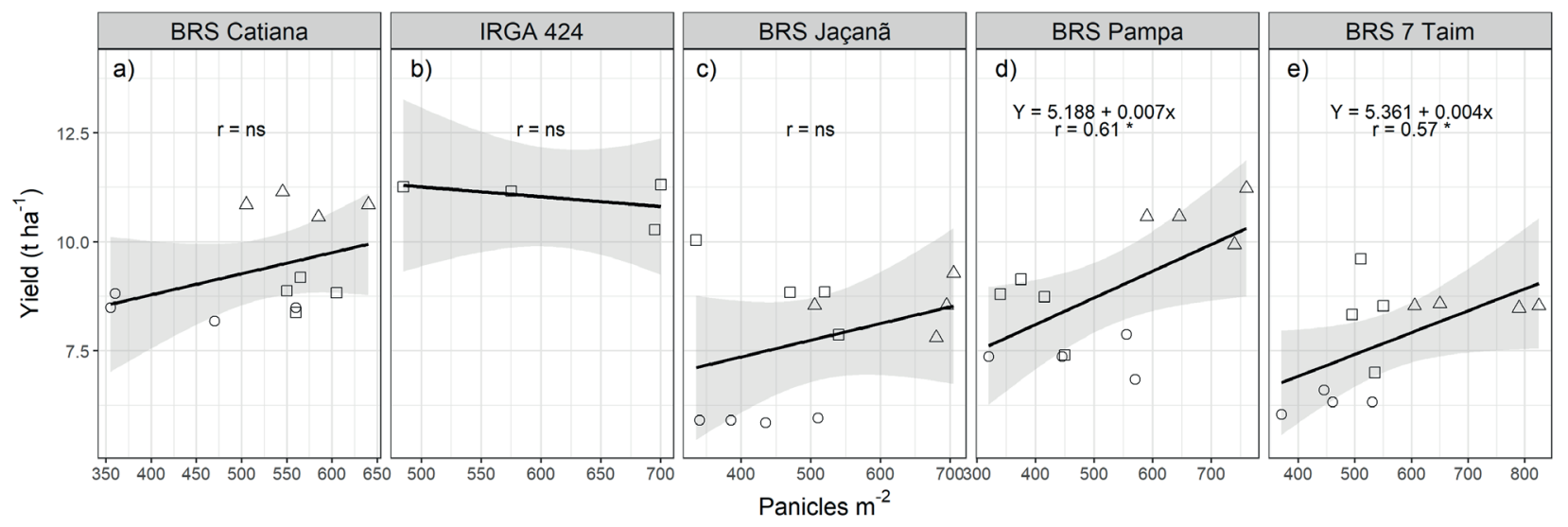

Figure 6. Grain yield for the BRS Catiana, IRGA 424, BRS Jaçanã, BRS Pampa and BRS 7 Taim cultivars, as a function of the number of panicles per $\mathrm{m}^{2}(\mathrm{a}, \mathrm{b}, \mathrm{c}, \mathrm{d}, \mathrm{e})$ at sowing times, in Goianira - GO. The black line and the gray area indicate the regression and the confidence interval at $5 \%$, respectively. r: coefficiente of correlation; ns: non-significant. 
than at SD1 and SD3, respectively (Figures 7a and 7b). Likewise, the yield/accumulated-PAR rate at SD2 was $7.1 \%$ and $8.3 \%$ higher than at SD1 and
SD3. These rates represent the grain production capacity per ${ }^{\circ} \mathrm{C} d$ and $\mathrm{MJ}$. The results show that, in Goianira, the sowing in November (SD2) had a

Table 2. Grain yield, accumulated degree-days and accumulated solar radiation for irrigated rice cultivars at three sowing times: SD1 (October), SD2 (November) and SD3 (December), in Goianira - GO, Cachoeirinha - RS and Pelotas - RS, in the 2014/2015 and 2015/2016 harvest years.

\begin{tabular}{|c|c|c|c|c|c|c|c|}
\hline Site & Time & BRS Catiana & BRS Jaçanã & BRS Pampa & BRS 7 Taim & IRGA 424 & Mean \\
\hline \multicolumn{8}{|c|}{ Grain yield $\left(t h^{-1}\right)$} \\
\hline \multirow{4}{*}{ Goianira - GO } & SD1 & $8.82 \mathrm{Bd}^{*}$ & $8.90 \mathrm{Bb}$ & $8.52 \mathrm{Bc}$ & $8.36 \mathrm{Bd}$ & $11.00 \mathrm{Ac}$ & $9.12 b$ \\
\hline & SD2 & $8.50 \mathrm{Ad}$ & $5.91 \mathrm{Cc}$ & 7.36 Bd & $6.33 \mathrm{Ce}$ & - & $7.02 \mathrm{c}$ \\
\hline & SD3 & $10.85 \mathrm{Ab}$ & $8.54 \mathrm{Bb}$ & $10.58 \mathrm{Ab}$ & $8.53 \mathrm{Bcd}$ & - & $9.63 b$ \\
\hline & SD1 & $10.61 \mathrm{Bb}$ & $11.63 \mathrm{Aa}$ & $10.07 \mathrm{Bb}$ & $9.45 \mathrm{Cbc}$ & $12.18 \mathrm{Ab}$ & $10.80 \mathrm{~b}$ \\
\hline \multirow[t]{2}{*}{ Cachoeirinha - RS } & SD2 & $11.49 \mathrm{Ba}$ & - & $13.17 \mathrm{Aa}$ & $10.19 \mathrm{Cab}$ & $13.23 \mathrm{Aa}$ & $12.02 \mathrm{a}$ \\
\hline & SD3 & 9.71 Ac & - & $10.68 \mathrm{Ab}$ & $10.59 \mathrm{Aa}$ & $9.86 \mathrm{Ad}$ & $10.21 \mathrm{~b}$ \\
\hline Pelotas - RS & $\mathrm{SD} 2$ & - & $8.57 \mathrm{Ab}$ & $5.99 \mathrm{Be}$ & $9.04 \mathrm{Acd}$ & - & $7.88 \mathrm{c}$ \\
\hline \multicolumn{8}{|c|}{ Accumulated degree-days $\left({ }^{\circ} \mathrm{C} d\right)$} \\
\hline \multirow{4}{*}{ Goianira - GO } & SD1 & $1,335 \pm 105$ & $1,116 \pm 98$ & $1,116 \pm 174$ & $1,116 \pm 99$ & $1,239 \pm 143$ & $1,184 \pm 124$ \\
\hline & SD2 & $1,412 \pm 223$ & $1,254 \pm 294$ & $1,177 \pm 247$ & $1,282 \pm 283$ & - & $1,281 \pm 262$ \\
\hline & SD3 & $1,239 \pm 295$ & $1,225 \pm 277$ & $1,198 \pm 263$ & $1,211 \pm 285$ & - & $1,218 \pm 280$ \\
\hline & SD1 & $1,674 \pm 292$ & $1,552 \pm 156$ & $1,376 \pm 200$ & $1,483 \pm 234$ & $1,552 \pm 192$ & $1,527 \pm 215$ \\
\hline \multirow[t]{2}{*}{ Cachoeirinha - RS } & SD2 & $1,651 \pm 250$ & - & $1,421 \pm 174$ & $1,499 \pm 216$ & $1,535 \pm 218$ & $1,527 \pm 214$ \\
\hline & SD3 & $1,627 \pm 278$ & - & $1,400 \pm 123$ & $1,387 \pm 203$ & $1,468 \pm 204$ & $1,471 \pm 202$ \\
\hline Pelotas - RS & SD2 & - & $1,447 \pm 279$ & $1,297 \pm 272$ & $1,422 \pm 239$ & - & $1,389 \pm 263$ \\
\hline \multicolumn{8}{|c|}{ Accumulated solar radiation $\left(\mathrm{MJ} \mathrm{m}^{-2}\right)$} \\
\hline \multirow{4}{*}{ Goianira - GO } & SD1 & $1,902 \pm 257$ & $1,618 \pm 223$ & $1,682 \pm 355$ & $1,682 \pm 257$ & $1,781 \pm 325$ & $1,733 \pm 283$ \\
\hline & SD2 & $1,936 \pm 202$ & $1,716 \pm 304$ & $1,589 \pm 241$ & $1,751 \pm 294$ & - & $1,748 \pm 260$ \\
\hline & SD3 & $1,753 \pm 502$ & $1,739 \pm 466$ & $1,706 \pm 434$ & $1,722 \pm 477$ & - & $1,730 \pm 470$ \\
\hline & SD1 & $2,676 \pm 399$ & $2,467 \pm 260$ & $2,168 \pm 343$ & $2,361 \pm 375$ & $2,467 \pm 318$ & $2,428 \pm 339$ \\
\hline \multirow[t]{2}{*}{ Cachoeirinha - RS } & SD2 & $2,578 \pm 376$ & - & $2,271 \pm 195$ & $2,375 \pm 268$ & $2,430 \pm 268$ & $2,413 \pm 277$ \\
\hline & SD3 & $2,317 \pm 453$ & - & $2,097 \pm 194$ & $2,084 \pm 314$ & $2,182 \pm 298$ & $2,170 \pm 315$ \\
\hline Pelotas - RS & SD2 & - & $2,347 \pm 517$ & $2,137 \pm 475$ & $2,303 \pm 441$ & - & $2,262 \pm 478$ \\
\hline
\end{tabular}

* Means followed by the same capital letter in the rows and small letter in the columns are not significantly different by the LSD test (0.05). The mean was compared between sites and as a function of sowing time.
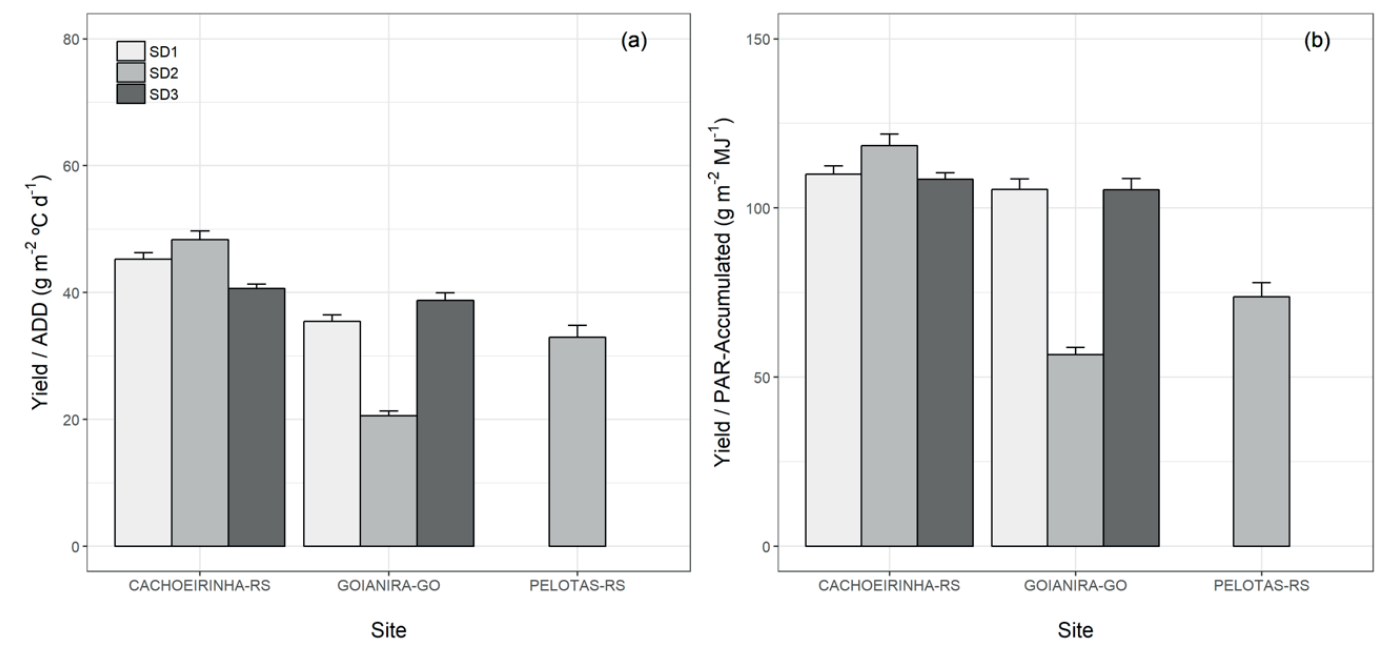

Figure 7. Yield per accumulated degree-days (ADD) $\left(\mathrm{G} \mathrm{m}^{-2}{ }^{\circ} \mathrm{C} \mathrm{d}^{-1}\right)(\mathrm{a})$ and yield per accumulated photosynthetically active radiation $\left(\mathrm{g} \mathrm{m}^{-2} \mathrm{MJ} \mathrm{d}^{-1}\right)(\mathrm{b})$, for sowing in October (SD1), November (SD2) and December (SD3), at the experimental sites. Vertical bars represent the mean error. 
lower yield potential than at SD1 and SD3, while, in Cachoeirinha, the greatest yield potential can be achieved at SD2, if compared with SD1 and SD3. In Pelotas, the yield rate was $26.3 \%$ lower than in Cachoeirinha and $4.36 \%$ higher than in Goianira. The higher yield in the tropical ecosystem, when compared to the subtropical ecosystem, found in this study, corroborates the results of Steinmetz et al. (2006), who pointed out that irrigated rice cultivars with the same yield potential have higher yields in the subtropical ecosystem.

The effect of temperature and global solar radiation on yield is evidenced in the reproductive and grain-filling phases, which had a positive correlation with yield (Figures $8 \mathrm{~b}, 8 \mathrm{e}, 8 \mathrm{c}$ and $8 \mathrm{f}$ ). This helps to understand the lower yields found in Goianira. Thus, the sowing of rice crops should be carried out in periods with low probability of extreme temperatures occurring over consecutive days (minimum $=15^{\circ} \mathrm{C}$ and maximum $=35^{\circ} \mathrm{C}$ ), in these phases.

A positive correlation was also found between grain yield and photosynthetically active accumulated radiation (PAR) over the period of 10 days before and 25 days after flowering, with absolute $r$ equal to $0.42(\mathrm{p}<0.05)$ (Figure 9). Similar results were reported by Tao et al. (2013) and Dingkuhn et al. (2015), whose absolute $r$ values were equal to 0.14 $(\mathrm{p}<0.01)$ and $0.10(\mathrm{p}<0.01)$, respectively, but smaller than the correlations found in the present study. The occurrence of a low solar radiation in this period significantly reduces the number and weight of spikelets, consequently reducing yield. In the reproductive and grain-filling phases, the demand for photoassimilates is high, because of the greater number of sink organs (panicles), if compared to the vegetative phase (leaves), requiring a higher energy balance of photosynthesis, which directly affects yield (Santos 2016). This characteristic of the rice plant has led to the search for sowing times that allow the reproductive and grain-filling phase to coincide with periods of greater daily availability of solar radiation. This indicates that specific management strategies, such as the use of modern cultivars and sowing time, should be adjusted to maximize the use

SD1 $\triangle \mathrm{SD} 2+\mathrm{SD} 3$
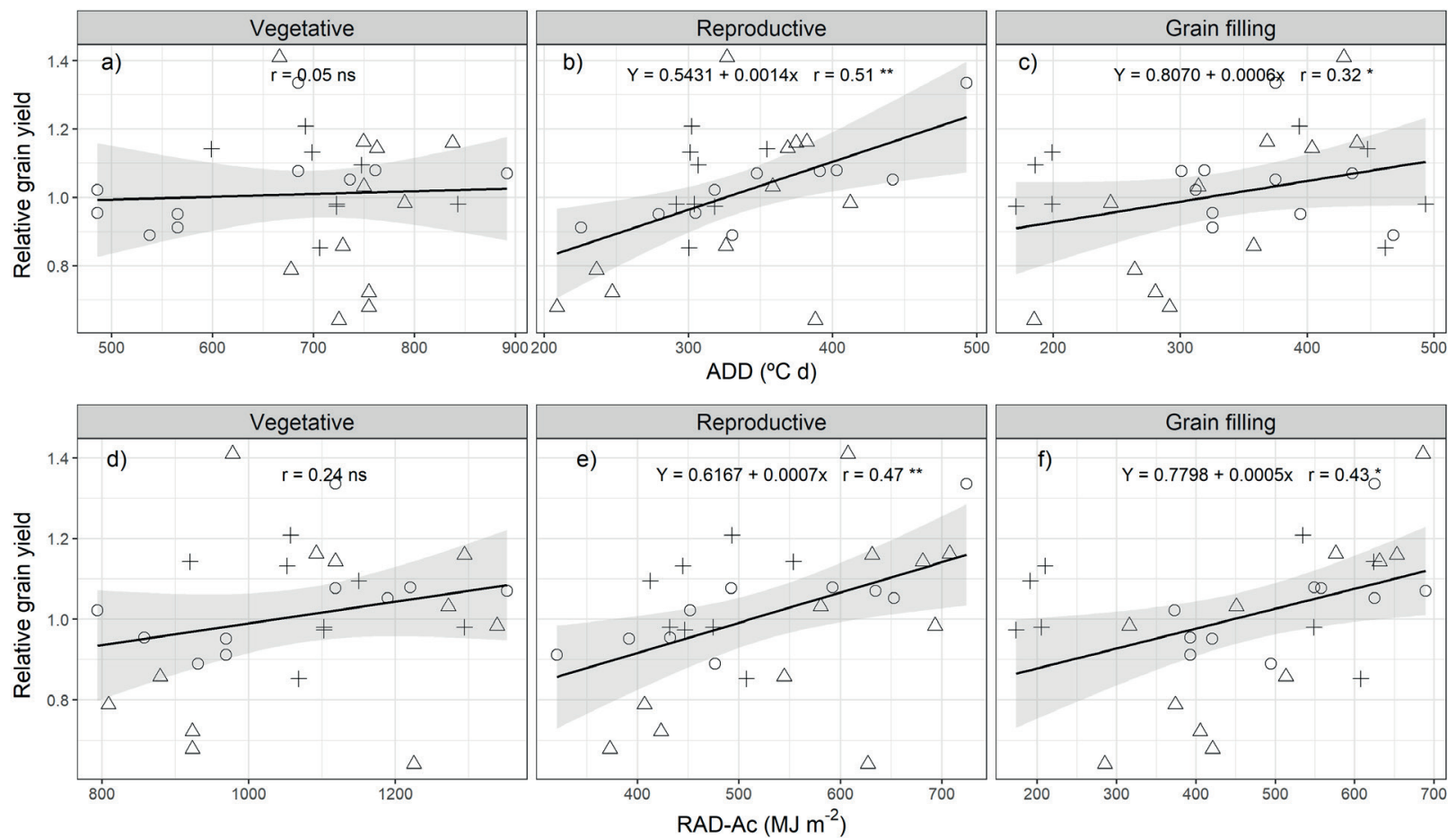

Figure 8. Correlations between the relative grain yield and accumulated degree-days (ADD), and between relative grain yield and accumulated global solar radiation (RAD-AC), during the vegetative (a, d), reproductive (b, e) and grain-filling (c, f) phases of five cultivars and three sowing dates: October (SD1), November (SD2) and December (SD3), in two crop sites $(n=29)$. * Significant at $5 \%$; ** significant at $1 \%$; ${ }^{\text {ns }}$ non-significant. The black line and the gray area indicate the regression and the confidence interval at $5 \%$, respectively. 


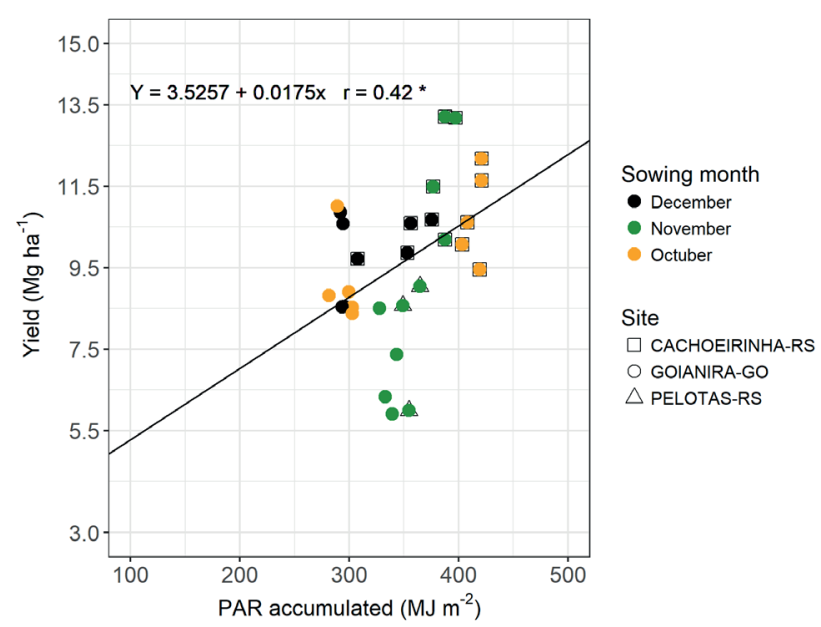

Figure 9. Grain yield, as a function of the photosynthetically active accumulated radiation (PAR), over the period of 10 days before and 25 days after flowering. * Significant at $5 \%$.

of solar radiation in the reproductive and grain-filling phases, according to the production ecosystem.

\section{CONCLUSIONS}

1. The tropical ecosystem has a lower yield potential than the subtropical ecosystem and a greater variability in the radiation use efficiency, as a function of the sowing dates;

2. In both ecosystems, the delay in sowing reduces the time to reach flowering, which is more evident in the tropical ecosystem;

3. The lower accumulation of minimum temperatures in the reproductive phase negatively affects grain yield, while the higher accumulation of degreedays and solar radiation during the reproductive and grain-filling phases contribute to high yields in irrigated rice production ecosystems, in Brazil. Thus, to maximize rice yield in irrigated rice crops, in Brazil, it is recommended that sowing times are planned for higher accumulation of degree-days and radiation during these development phases.

\section{REFERENCES}

ACRECHE, M. M. et al. Radiation interception and use efficiency as affected by breeding in Mediterranean wheat. Field Crops Research, v. 110, n. 2, p. 91-97, 2009.

ALVARES, C. A. et al. Köppen's climate classification map for Brazil. Meteorologische Zeitschrift, v. 22, n. 6, p. 711-728, 2014.
BOUMAN, B. A. M. et al. ORYZA 2000: modeling lowland rice. Manila: IRRI, 2001.

BRESEGHELlO, H. C. de P.; NEVES, P. de C. F. Arroz irrigado subtropical: desenvolver a cadeia produtiva do arroz irrigado em ambiente subtropical por meio de colaborações com instituições parceiras. 2016. Available at: <https://www.embrapa.br/arroz-e-feijao/inovacaotecnologica/arroz-irrigado-subtropical $>$. Access on: 23 Jan., 2017.

COUNCE, P. A.; KEISLING, T. C.; MITCHELL, A. J. A uniform, objective, and adaptive system for expressing rice development. Crop Science, v. 40, n. 2, p. 436-443, 2000.

DALCHIAVON, F. C. et al. Correlação linear entre componentes da produção e produtividade do arroz de terras altas em sistema plantio direto. Semina: Ciências Agrárias, v. 33, n. 5, p. 1629-1642, 2012.

DENG, N. et al. Influence of temperature and solar radiation on grain yield and quality in irrigated rice system. European Journal of Agronomy, v. 64, n. 1, p. 37-46, 2015.

DINGKUHN, M. et al. Improving yield potential of tropical rice: achieved levels and perspectives through improved ideotypes. Field Crops Research, v. 182, n. 1, p. 43-59, 2015.

FAN, H.; LIU, X. Comparison and optimization of various non-dimensionalized methods based on comprehensive evaluation method: a case study of land development in Yongdeng county of Lanzhou city. Hunan Agricultural Sciences, v. 17, n. 1, p. 163-166, 2010.

FIOREZE, S. L.; RODRIGUES, J. D. Tillering affected by sowing density and growth regulators in wheat. Semina: Ciências Agrárias, v. 35, n. 2, p. 589-604, 2014.

GUNAWARDENA, T. A.; FUKAI, S.; BLAMEY, F. P. C. Low temperature induced spikelet sterility in rice: I. Nitrogen fertilisation and sensitive reproductive period. Australian Journal of Agricultural Research, v. 54, n. 10, p. 937-946, 2003.

HEINEMANN, A. B. et al. Upland rice cultivar responses to row spacing and water stress across multiple environments. Experimental Agriculture, v. 10, n. 1, p. 1-18, 2016.

KERBAUY, G. B. Fisiologia vegetal. São Paulo: Guanabara Koogan, 2008.

KRISHNAN, P. et al. Impact of elevated $\mathrm{CO}_{2}$ and temperature on rice yield and methods of adaptation as evaluated by crop simulation studies. Agriculture, Ecosystems and Environment, v. 122, n. 2, p. 233-242, 2007.

LIMA, E. V.; CRUSCIOL, C. A. C.; MATEUS, G. P. Participação do colmo principal e dos afilhos na 
produtividade do arroz irrigado, em função da densidade de semeadura. Bragantia, v. 69, n. 2, p. 387-393, 2010.

LORENÇONI, R.; DOURADO NETO, D.; HEINEMANN, A. B. Calibração e avaliação do modelo ORYZA-APSIM para o arroz de terras altas no Brasil. Revista Ciência Agronômica, v. 41, n. 4, p. 605-613, 2010.

MARTINS, A. F. et al. Caracterização de famílias mutantes de arroz para tolerância ao frio nos períodos vegetativo e reprodutivo. Bragantia, v. 66, n. 2, p. 227-233, 2007.

NASCENTE, A. S.; SANTOS, B. M. dos. Arroz irrigado tropical: desenvolver tecnologias para sustentabilidade do sistema de produção de arroz irrigado em ambiente tropical. 2016. Available at: <https://www.embrapa. br/arroz-e-feijao/inovacao-tecnologica/arroz-irrigadotropical>. Access on: 23 Jan., 2017.

RAY, D. K. et al. Climate variation explains a third of global crop yield variability. Nature Communications, v. 22, n. 1, p. 1-9, 2015.

SANTOS, H. G. dos et al. (Eds.). Sistema brasileiro de classificação de solos. 3. ed. Brasília, DF: Embrapa, 2013.

SANTOS, M. P. dos. Produtividade de grãos e características morfofisiológicas de arroz irrigado afetadas por local e época de semeadura. 55 f. 2016. Dissertação (Mestrado em Agronomia) - Universidade Federal de Goiás, Goiânia, 2016.

SOCIEDADE BRASILEIRA DO ARROZ IRRIGADO (Sosbai). Arroz irrigado: recomendações técnicas da pesquisa para o Sul do Brasil. In: REUNIÃO TÉCNICA DA CULTURA DO ARROZ IRRIGADO, 31., 2016, Bento Gonçalves. Available at: $<$ http://www.sosbai.com.br/docs/ Boletim_RT_2016.pdf>.Access on: 22 Jul., 2017.
STEINMETZ, S. et al. Determinação dos graus-dia e do número de dias para atingir o estádio de diferenciação da panícula de cultivares de arroz irrigado. Pelotas: Embrapa Clima Temperado, 2009. (Boletim de pesquisa e desenvolvimento, 88).

STEINMETZ, S.; SILVA, S. C.; SANTANA, N. M. P. Clima. In: SANTOS, A. B.; STONE, L. F.; VIEIRA, N. R. A. (Eds.). A cultura do arroz no Brasil. 2. ed. Santo Antônio de Goiás: Embrapa Arroz e Feijão, 2006. p. 117-160.

STRECK, E. V. et al. Solos do Rio Grande do Sul. 2. ed. Porto Alegre: UFRGS, 2008.

TAO, F. et al. Single rice growth period was prolonged by cultivars shifts, but yield was damaged by climate change during 1981-2009 in China, and late rice was just opposite. Global Change Biology, v. 19, n. 10, p. 3200-3209, 2013.

TEIXEIRA, G. C. da S.; STONE, L. F.; HEINEMANN, A. B. Eficiência do uso da radiação solar e índices morfofisiológicos em cultivares de feijoeiro. Pesquisa Agropecuária Tropical, v. 45, n. 1, p. 9-17, 2015.

VAN OORT, P. A. J. et al. Correlation between temperature and phenology prediction error in rice (Oryza sativa L.). Agricultural and Forest Meteorology, v. 151, n. 12, p. 1545-1555, 2011.

WASSMANN, R. et al. Regional vulnerability of climate change impacts on Asian rice production and scope for adaptation. Advances in Agronomy, v. 102, n. 1, p. 91133, 2009.

ZIBAEE, A. Rice: importance and future. Rice Research, v. 1, n. 2, p. 1, 2013. 